\title{
Exploring antecedents of business angels' intention to invest
}

\author{
Mateja Drnovšek ${ }^{1}$, Sanda Franić2 ${ }^{2}$ Alenka Slavec ${ }^{3}$
}

\begin{abstract}
In this research, we use regulatory focus theory to explore the cognitive mechanisms that contribute to the formation of business angels'intention to invest. Although prior literature has argued that perceived desirability and perceived feasibility are the two main antecedents of the intentional behavior of entrepreneurs, little is known about the antecedents of the intentional behavior of business angels. We address this gap by linking the role of regulatory focus and entrepreneurial alertness to the formation of investment intentions. We begin by collecting qualitative data via semi-structured interviews with business angels to gain a broad perspective on business angels' intentional behavior, their goals, planning activities and several characteristics related to cognition. We collected survey data from an international sample of business angels to find that entrepreneurial alertness with its scanning and search dimension plays an important role in intentionality. Furthermore, business angels that have promotion regulatory focus are more likely to form investment intentions.
\end{abstract}

Key words: intention to invest, entrepreneurial alertness, regulatory focus, cognitive style, risk propensity

JEL classification: $D 81$

* Received: 20-03-2018; accepted: 14-12-2018

1 Full professor, Faculty of Economics, University of Ljubljana, Academic unit for entrepreneurship (department chair), Kardeljeva pl. 17, Ljubljana, Slovenia. Scientific affiliations: psychology of entrepreneurs, academic entrepreneurship. Phone: +386 15892 613. E-mail:mateja.drnovsek@ef.uni-lj.si. Website: www.ef.uni-lj.si (corresponding author).

2 Ph.D. Candidate, Faculty of Economics, University of Ljubljana, Kardeljeva pl. 17, Ljubljana, Slovenia. Scientific affiliation: psychology of business angels. E-mail: sanda.franic@mstintersped.hr.

3 Assistant professor, Faculty of Economics, University of Ljubljana, Academic unit for entrepreneurship, Kardeljeva pl. 17, Ljubljana, Slovenia. Scientific affiliation: psychology of entrepreneurs, financing in entrepreneurship. Phone: + 38615892 613. E-mail: alenka. slavec@ef.uni-lj.si.Website: www.ef.uni-lj.si. 


\section{Introduction}

Business angels serve as the most important direct source of early-stage risk capital to entrepreneurs (Mason, 2006) and constitute a critical financial source, filling the gap between founders, family and friends, and institutional funds (White and Dumay, 2017). In its 2016 statistics compendium, the European Trade Association for Business Angels, Seed Funds and Early Stage Market Players' (EBAN) estimated that the European early-stage investment market was worth 9.9 billion Euros. The biggest share of that investment ( 6.7 billion Euros) belonged to business angels, followed by venture capital funds ( 2.5 billion Euros) and the rapidly growing area of equity crowdfunding investments. The number of business angels in Europe is estimated at upwards of 300,000. In south-east European countries (such as Slovenia, Serbia, Macedonia, Croatia, and Kosovo), 193 business angels were registered through EBAN in 2016, with 90 investments worth 8.8 million Euros. In these countries, the average investment per business angel network (BAN) was 1.76 million Euros, while the European average per BAN was 2.37 million Euros. Anecdotal evidence suggests that there is an even greater number of unregistered (e.g. invisible) business angels, but there are no official data about them and their activities.

Given that public policy in both developed and developing countries has focused on start-up companies as propellers of innovation and economic growth (Mason et al., 2016), it is important to understand what individual-level processes impact business angels' intention to invest. In studying angel investors, prior researchers have argued (Lindsay, 2004) that entrepreneurs and business angels are alike in terms of the determinants and dynamics of their decision-making strategies and processes when acting upon opportunities. Prior research on business angels has mainly focused on the impact of the investor's age, work experience, opportunity evaluation, and degree of involvement; different stages of the investment process; and exit strategies (Moen et al., 2008). Researchers have also explored how the cognitive processes of business angels are linked to the distinct stages of the investment process (Maxwell et al., 2011). As business angels pass through these different stages, they try to determine the deal that best fits with their personal investment goals (Mitteness et al., 2012). This stream of research, however, does not shed sufficient light on the antecedents and mechanisms that support the formation of business angels' investment intentions. In this study, we aim to explain how different individual cognitive and motivational factors shape business angels' intention to invest. We explore the role of determinants related to opportunity recognition (i.e., entrepreneurial alertness, regulatory focus, cognitive style, and risk propensity) in the context of business angels. To do so, we develop a theoretical model of angels' intentionality and empirically test the proposed relationships. This knowledge has important implications for supporting business angels' investmentrelated decision-making processes. 
We contribute to the literature by examining the role played by business angels' regulatory focus and entrepreneurial alertness in the formation of investment intentions. Even though scholars have long recognized the varying impact of regulatory focus at the different stages of the entrepreneurial process (Brockner et al., 2004; e.g., in opportunity recognition [Tumasjan and Braun, 2012] and opportunity exploitation [McMullen and Shepherd, 2006; Hmieleski and Baron, 2008]), there is scant evidence on how regulatory focus impacts business angels' behaviors. Second, we extend the body of knowledge on entrepreneurial alertness by examining its role in the formation of investment intentions. Drawing on the cognitive approach to the alertness process (Tang et al., 2012; Amato et al., 2016), we examine the three dimensions of entrepreneurial alertness and their relationship to angels' intention to invest. However, in this study, we highlight the role of entrepreneurial alertness as an antecedent of emergence of intent to invest rather than its role in the opportunity identification context. Showing how the three dimensions of entrepreneurial alertness relate to investment intentions has important practical implications for business angels (Valliere, 2013). In particular, this knowledge can facilitate their learning process by integrating new information and overcoming the psychological barriers associated with investment decisions. During the investment process, establishing a better fit in the angel-entrepreneur dyad in terms of angels' psychological characteristics will benefit not only the entrepreneurs and business angels, but also policy creators, business schools, and consulting educators, who could develop more effective support, advice, teaching, and practical training to improve success on both sides of the dyad.

\section{Literature review}

\subsection{The investment process as planned behavior}

We review the literature on the investment process as intentional behavior, given that it precedes decision-making and action (Shirokova et al., 2016). Such behavior involves thinking about potential future actions, processing information cues from the environment, and engaging in careful planning and analysis (Dimov, 2007). Entrepreneurial intention is a function of the perceived feasibility and perceived desirability of a new venture (Krueger Jr et al., 2000). In this study, intention refers to the conscious and planned state of mind that directs and guides business angels toward specific actions (Boyd and Vozikis, 1994). The process of forming an intention relies on angels' cognitive schemas that guide attention and information processing. Schemas are complex and adaptive mental frameworks that individuals use to "make sense of the world" (Valliere, 2013), or frameworks through which new information acquires meaning. Cognitive flexibility, that is, the ability to notice the relationship between two disparate pieces of information (Foo et al., 2015), helps business angels to identify profit opportunities. Whereas "opportunity" for 
entrepreneurs is tied to a venture idea (Davidsson, 2003), for business angels it is tied to an investment opportunity (Alvarez and Barney, 2007).

The theory of planned behavior (Ajzen, 1991) outlines three attitudinal antecedents of intention. The first two antecedents - personal attitudes toward behavioral outcomes and perceived social norms - reflect perceived desirability. The third - perceived behavioral control - is related to the perceived feasibility of performing the planned behavior. Revisiting Ajzen's (1991) theory, we argue that business angels may be motivated by the investment's favorable (i.e., profit maximization) and unfavorable (i.e., risk exposure) outcomes. Entrepreneurial alertness, regulatory focus, and cognitive style represent angels' cognitive resources, each of which is linked to the idea of profit maximization. These determinants frame business angels' perception of an investment's feasibility and desirability (Fitzsimmons and Douglas, 2011), thereby influencing their intention to invest. We discuss these ideas below.

\subsection{Entrepreneurial alertness}

Entrepreneurial alertness is defined as an individual's ability to see opportunities where others do not (Kirzner, 1979). Cognitive abilities related to prior knowledge, experiences, creativity, and general mental ability constitute a base for entrepreneurial alertness and influence individuals' information processing (Gielnik et al., 2014). Recently, Tang et al. (2012) defined entrepreneurial alertness as a process consisting of three sequential stages that enhance the individual's ability to recognize new opportunities: scanning and search, association and connection, and evaluation and judgment. In the scanning and search stage, entrepreneurs are relentless in searching for information and seek to build a broad knowledge base of domain-specific information; such information combined with the individual's knowledge base builds grounds for opportunity identification (Tang et al., 2012). The function of one's existing knowledge base is to moderate the collection of new knowledge, to fit new knowledge with existing knowledge, and to accommodate new situations. The association and connection stage relates to entrepreneurs' cognitive ability to "connect the dots" between diverse material (Baron, 2006) by receiving new information and integrating it into an existing cognitive framework. When a broader perspective is formed, entrepreneurs may need to repeat the scanning and search stage in order to make adjustments or fine-tune the search to produce more associations. Evaluation and judgment is the final stage of the alertness process, wherein entrepreneurs determine whether an opportunity is worth pursuing. This stage is crucial for identifying opportunities and evaluating whether opportunities fit with the entrepreneur's existing cognitive framework.

Transferring these findings to research on business angels, we observe that the feedback that business angels receive during an entrepreneur's presentation/pitch shapes their perception of whether or not the investment constitutes an opportunity 
(Amato et al., 2016). Even though angels cannot influence the intensity of environmental change (Shane, 2003), they can keep their cognitive schemas activated at a level at which they can be triggered by even the smallest stimuli. As such, their schemas continuously develop through experience and repetition, creating strong associations between particular stimuli. At this very early stage of the investment process, scanning and search is expected to have the most significant influence. As business angels search for information (Kaish and Gilad, 1991), scanning and search mechanisms increase the likelihood of business angels identifying important events and trends, and thus adapting to environmental shifts (Stewart et al., 2008). This leads us to propose the following hypothesis $(\mathrm{H} 1 \mathrm{a} \& \mathrm{H} 1 \mathrm{~b} 6 \mathrm{H} 1 \mathrm{c})$ :

- The scanning and search dimension of entrepreneurial alertness is positively associated with business angels' intention to invest.

- The association and connection dimension of entrepreneurial alertness is positively associated with business angels' intention to invest.

- The evaluation and judgment dimension of entrepreneurial alertness is positively associated with business angels' intention to invest.

\subsection{Regulatory focus}

Regulatory focus theory (Higgins, 1997, 1998) describes an individual's orientation toward future goals by explaining how goal-directed behavior is regulated by two distinct, asymmetric self-regulatory mindsets: promotion focus and prevention focus. Both foci integrate an individual's motivation to achieve desired end-states and avoid undesired end-states, balancing between potential benefits and potential losses. Promotion-focused individuals are motivated to accomplish goals through growth, trying to reach their ideal selves (Higgins, 1997). Such individuals may thus be more likely to identify new investment opportunities. By contrast, prevention-focused individuals are motivated by security, duty, and responsibility when striving toward their goals, and tend to avoid errors of commission (Higgins, 1997).

We argue that these two foci are particularly crucial during the early stage of the investment decision-making process. Prior research on regulatory focus (Crowe and Higgins, 1997) has shown that promotion-focused individuals tend to primarily detect those signals that justify a positive response, while prevention-focused individuals tend to avoid making mistakes and thus prefer a negative response. The entrepreneurial intention of promotion-focused individuals increases as the subjectively perceived benefits of entrepreneurial action increase (McMullen and Shepherd, 2002). In the early stage of the entrepreneurial process, Tumasjan and Braun (2012) found that entrepreneurs' promotion focus positively influences opportunity identification. By contrast, in the pre-selection stage, prevention focus 
slows down the formation of an investment intention, since prevention-focused business angels would rather avoid investments with pure potential than "pick" winners (Mason and Harrison, 2002a). Given the focus on avoiding potential losses, a prevention focus mindset is likely to emerge after the intention has been established and the entrepreneur must assess the feasibility of the investment. Accordingly, we propose the following hypotheses (H2\&H3):

- Promotion focus is positively associated with intention to invest.

- Prevention focus is negatively associated with intention to invest.

\subsection{Cognitive style}

Witkin et al. (1977: 15) defined cognitive style as "individual differences in the way people perceive, think, solve problems, learn and relate to others." Such cognitive differences emerge as individuals adapt to their external context through specific cognitive abilities and personality traits (Kozhevnikov et al., 2014). In an entrepreneurial context, cognitive style refers to one's decision-making style and higher-level information processing. Specific cognitive styles are suited to different phases of the entrepreneurial process (Krueger Jr. and Kickul, 2006), including the formation of entrepreneurial intentions (Barbosa et al., 2007). Individuals with a planning cognitive style use a narrow range of solutions to problems; they apply a traditional, conservative approach to increase efficiency, and they are loyal to conventional rules (Cools and Van den Broeck, 2007). Notably, they dedicate a lot of time to planning and preparation in order to reach their goals. Because they are more rigorous in processing information before making decisions, they tend to be less susceptible to risk (Barbosa et al., 2007) and insist on respect for rules and agreements. Prior research suggests that when entrepreneurs adopt a planning cognitive style, they tend to think linearly and rationally. Previous findings have also indicated that, during the investment decision-making process, business angels make plans and focus on commercial outcomes (Mason and Harrison, 2008). Thus, we propose (H4):

- Planning cognitive style is positively associated with intention to invest.

\subsection{Risk propensity}

Risk propensity is an individual's tendency "either to take or to avoid risk" (Sitkin and Pablo, 1992: 12). Risk propensity is a personality trait that is directly related to an individual's decision-making behavior (Zhang and Cain, 2017). Risk propensity is not a stable trait because it depends on the level of domain experience (Bryant and Dunford, 2008). It becomes more stable as domain experience increases over time. Differences in individuals' risk propensity inform their risk perception and behavior related to possible decision outcomes (Forlani and Mullins, 2000). 
Entrepreneurship research has examined several drivers of individuals' risk perception. For example, Palich and Ray Bagby (1995) confirmed previous findings that entrepreneurs employ different heuristics and biases that are negatively associated with risk perception (Keh et al., 2002). When faced with information overload in the process of forming an intention to invest, business angels choose which information to select, encode, and process. Business angels with a higher risk propensity will perceive fewer risks related to a potential investment opportunity than those who have a lower risk propensity (Sitkin and Weingart, 1995; Forlani and Mullins, 2000). Taken together, these studies highlight the importance of risk propensity for the decision-making process related to a new venture; they also suggest that risk propensity may be a potential antecedent to the formation of business angels' intention to invest. In turn, these findings suggest the following hypothesis (H5):

- Risk propensity is positively associated with intention to invest.

Figure 1: Proposed theoretical model integrating entrepreneurial alertness, regulatory focus, planning cognitive style and risk propensity

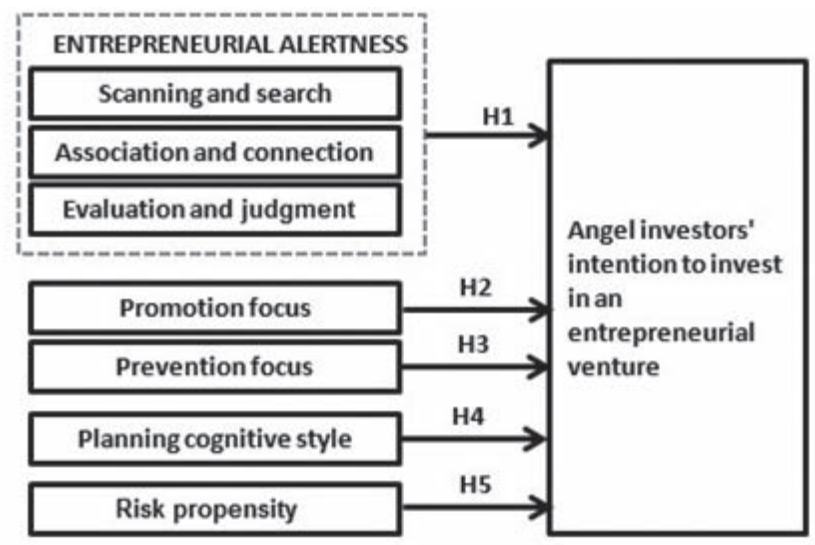

Source: Author's derivation

In the proposed framework (Figure 1), we integrate ideas from the theory of planned behavior (Ajzen, 1991), entrepreneurial alertness (Kirzner, 1979), regulatory focus (Higgins, 1997, 1998), cognitive style (Witkin et al., 1977), and risk propensity (Forlani and Mullins, 2000). This framework suggests that entrepreneurial alertness, promotion focus, prevention focus, and risk propensity directly influence business angels' intention to invest. Entrepreneurial alertness makes business angels open to collecting new domain-specific knowledge - a process that is supported by promotion focus and planning cognitive style. Higher risk propensity leads to the perception of less risk and thus facilitates the formation of an investment intention. 


\section{Methodology}

\subsection{Research design}

In order to understand what cognitive processes are important in business angels' decision-making, we used an exploratory mixed methods approach (Bryman, 2006; Greene, 2007). Mixed methods approaches incorporate both qualitative and quantitative techniques at each stage of the research (Johnson and Onwuegbuzie, 2004) and pay particular attention to firmly related phenomena (Creswell, 2003). As our goal was to examine the intangible mechanisms underlying business angels' intention to invest, rather than to analyze investment outcomes, qualitative data further assisted us in the interpretation, clarification, description, and validation of the quantitative results (Johnson et al., 2007). Qualitative and quantitative data were collected during the first quarter of 2015 from two independent sources: semistructured, open-ended interviews and an online survey.

\subsection{Qualitative study among business angels}

In order to aid to the conceptual development of the study and have grounds for selecting constructs and their scales in the quantitative survey we decided to start our empirical research by conducting semi-structured interviews with business angels. We expected that business angels would provide information that illuminated their personal attitudes and perceptions on aspects related to investment decision-making.

The recruitment process for the personal interviews was carried out through e-mails and telephone calls to encourage business angels to participate in the research. Because business angels tend to prefer anonymity (Wetzel, 1983), the support from EBAN and word of mouth from the initial contacts helped us to recruit volunteers for the interview from the hidden population (Mason et al., 2017). The first criterion for selecting the 20 business angels controlled for their past investment experience in executing early-stage funding deals. To ensure the reliability of the information provided by participants, we followed Wiltbank and colleagues' (2009) list of tangible baseline factors identified as significant in the context of business angels' investment process, for example, the number of total venture investments, investment experience, entrepreneurial experience, the number of investments made in the seed-stage, and due diligence. We conducted 16 interviews via Skype with participants located in Austria, Denmark, England, Estonia, Finland, France, Germany, Switzerland, and the United States, and four face-to-face interviews with participants from Austria, Slovenia, Switzerland, and the United States. To minimize potential shortfalls between different native speakers (Brislin, 1970), all interviews were conducted in English. The selected business angels were middleaged (an average of 52 years of age), male (90\%), self-employed consultants 
(80\%). They were highly experienced in entrepreneurship $(80 \%$ had founded one or multiple businesses; the other $20 \%$ had participated in managers' buy-out/ buy-in), with an average number of 3.34 start-ups founded. Most of them (90\%) invested financial resources in conventional angel investments $(85 \%)$. The focus of investment interest was on technology-based firms (40\%), and the majority invested in both technology- and non-technology-based firms (60\%). All together they invested in deals with a median of 10 completed deals, a figure similar to that of Mason and colleagues' (2017) study. By comparing the sample in this study to recent studies of business angels by Mason et al. (2017) and Mason and Botelho (2014), we can authenticate the representativeness of the sample.

We asked participants broad, open-ended questions related to their typical habits during the investment process. To foster a relaxing atmosphere, we started with questions about their background, work experience, investment experience, motivation for investment, and current work status. The participants were not informed of the particular focus of the research (e.g., business angels' cognitive processes); we told them that we were exploring business angels' decision-making behavior in order to avoid potential self-report bias. Each interview lasted one hour. We took manual notes instead of recording the participants in order to avoid any visual and emotional pressure on participants (Bryman, 2006). We used the same set of questions for all interviews throughout the interview process. The list of interview questions is given in Appendix A.

\subsection{Quantitative study among business angels}

The empirical sample for the research was compiled through an online survey among business angels from Europe (EBAN) and the United States (ACA). We sent the survey link to 343 angel groups in Europe and 273 in United States, and 87 completed surveys were returned (15\% response rate). After eliminating 32 incomplete surveys, the dataset for quantitative analysis was drawn from 55 valid responses. Such sample size met the size requirements established by using Monte Carlo simulations (Wolf et al. 2013). In Wolf and colleagues' (2013) case, a sample size of 50 participants was required to achieve minimal bias, adequate statistical power, and overall propriety (in the case of single-factor CFA models with eight indicators with loadings of 0.65 ).

Respondents were mostly male (94\%) and on average 54 years old (ranging from 34 to 73 years old). More than half of the business angels in the sample were from European countries (53\%), and 47\% were from the United States. Among European countries, the largest percentage of participants was from Switzerland (20\%).

The results of the non-response bias analysis (Armstrong and Overton, 1977) demonstrated that there were no statistically significant differences between the groups in alert scanning and search $(p=0.743)$, alert association and connection $(p$ 
$=0.878)$, alert evaluation and judgment $(p=0.831)$, promotion focus $(p=0.254)$, prevention focus $(p=0.335)$, planning cognitive style $(p=0.318)$, risk propensity $(p=0.348)$, or intention to invest $(p=0.645)$. Since no significant differences were found, it was concluded that non-response bias was not a concern in this study.

Certainly, identifying business angels through business angel networks may have excluded data from non-registered angels or from angels who lacked success and so left the groups, suggesting presence of survivor bias and self-selection bias (Harrison and Mason's, 2007).

There are marked similarities between the demographic characteristics of the respondents in our sample and those of the largest sample of business angels (Mason and Botelho, 2014). In our sample, 75\% of business angels had at least a university degree and $48.6 \%$ had a postgraduate (Master's or MBA) degree. The only statistically significant differences between the samples were in the mean age of 54 years and the $6 \%$ share of women angels. However, these differences were not sufficiently significant to warrant a re-examination of the sample's reliability, particular with respect to the lack of gender diversity (Harrison and Mason, 2007).

\subsubsection{Measures}

\subsubsection{Dependent variable}

Entrepreneurial intent was measured using Chen et al.'s (1998) entrepreneurial decision scale, which consists of items assessing individuals' intention to start a business. The original measure assesses entrepreneurial intention with five items on a 5-point Likert scale ( $1=$ very unlikely; $5=$ very likely). Respondents were asked to indicate the likelihood of engaging in certain investment activities over the following year. Confirmatory factor analysis results in good overall fit of the model after addition of one error covariance between similarly worded items (RMSEA = 0.07 ;FI $=0.99 ; \mathrm{NNFI}=1 ; \mathrm{CFI}=1 ; \mathrm{IFI}=1, \mathrm{SRMR}=0.01 ; \mathrm{SB} \chi^{2}=5.15 ; \mathrm{df}=4$; $\mathrm{p}=0.272)$.

\subsubsection{Independent variables}

Entrepreneurial alertness was measured using a 13-item scale developed by Tang et al. (2012). This is a 7-point Likert-type scale ranging from $1=$ never to $7=$ always and includes three dimensions: scanning and search, association and connection, and evaluation and judgment. The scanning and search dimension was assessed with six items (e.g., I have frequent interactions with others to acquire new information); association and connection was assessed with three items (e.g., I see links between seemingly unrelated pieces of information); and evaluation and judgment was assessed with four items (e.g., I have a gut feeling for potential opportunities). The fit 
indices of the measurement model for entrepreneurial alertness scale indicated good model fit $(\mathrm{RMSEA}=0.05 ; \mathrm{NFI}=0.98 ; \mathrm{NNFI}=0.99 ; \mathrm{CFI}=1 ; \mathrm{IFI}=1, \mathrm{SRMR}=0.03$; $\left.\mathrm{SB} \chi^{2}=59.4 ; d f=49 ; p=0.146\right)$, supporting convergent and discriminant validity.

Regulatory focus was measured using the 11-item regulatory focus scale developed by Higgins and colleagues (2001). The scale assesses the history of individuals' success at promotion and prevention tasks in their lives. Regulatory focus was scored on a 5-point Likert-type scale ( $1=$ never or seldom; $5=$ very often). Scale items included, for example, Compared to most people, are you typically unable to get what you want out of life?; and How often did you obey rules and regulations that were established by your parents? The fit indices in the measurement model for the regulatory focus scale demonstrated good overall fit $(\mathrm{RMSEA}=0.08$; NFI $=$ $0.93 ; \mathrm{NNFI}=0.97$; CFI $=0.99 ; \mathrm{IFI}=0.99, \mathrm{SRMR}=0.05 ; \mathrm{SB} \chi^{2}=25.6 ; d f=19 ; p$ $=0.141)$.

Planning cognitive style was assessed using the cognitive style indicator (CSI) scale (Cools and Van den Broeck, 2007) and measured on a 7-point Likert-type scale (1=totally disagree to $7=$ totally agree). The CSI consists of seven items measuring the planning style dimension (e.g., I prefer clear structures to do my job). The fit indices in the measurement model for the planning cognitive style demonstrated good overall fit $(\mathrm{RMSEA}=0 ; \mathrm{NFI}=0.98 ; \mathrm{NNFI}=1 ; \mathrm{CFI}=1$; $\mathrm{IFI}=1$, $\mathrm{SRMR}=$ $\left.0.02 ; \mathrm{SB} \chi^{2}=6.77 ; d f=8 ; p=0.561\right)$.

Risk propensity was measured using the riskiness dimension taken from the strategic orientation of business enterprise (STROBE) scale (Venkatraman, 1989) and scored on a 7-point Likert scale (1=strongly disagree, $7=$ strongly agree). The measurement model fit of risk propensity scale indicated good model fit (RMSEA $=0.03 ; \mathrm{NFI}=0.98 ; \mathrm{NNFI}=0.99 ; \mathrm{CFI}=0.99 ; \mathrm{IFI}=0.99, \mathrm{SRMR}=0.03 ; \mathrm{SB} \chi^{2}=$ $2.13 ; d f=2 ; p=0.346)$.

\subsubsection{Control variables}

The country of origin was considered as a control to check for differences between the American and European angels with respect to their intention to invest. Second, the investor's entrepreneurial experience was considered as a control variable, because the investor's prior knowledge and experience is likely to impact his/her intention to invest (e.g., Tumasjan and Braun, 2012). Investor's experience was assessed according to the baseline of factors Wiltbank et al. (2009) identified as being important for angel investors. The baseline model includes total venture investments, investment experience, entrepreneurial experience, due diligence, deals through personal relationships, prior investments, and post-investment participation. The overall fit of the measurement model for investor's experience was good $(\mathrm{RMSEA}=0.04 ; \mathrm{NFI}=0.94 ; \mathrm{NNFI}=1 ; \mathrm{CFI}=1 ; \mathrm{IFI}=1, \mathrm{SRMR}=0.07$; $\left.\mathrm{SB} \chi^{2}=36 ; d f=34 ; p=0.373\right)$. Composite reliability was 0.93 . 


\section{Results of empirical analysis and discussion}

\subsection{Results from qualitative study}

We employed an inductive perspective to analyze the interviews. We aimed to identify different levels of intention to invest; to discover if selected business angels had past investment experience; to identify patterns related to alertness for new information; to identify angels' goals; to collect data on the amount of time business angels dedicate to planning activities and their motivation for investing; and finally to determine angels' risk propensity.

The interview data were open-coded for themes related to different facets of the decision-making process in the context of investment decisions. We coded transcripts specifically to identify the degree of investment intention. Intention to invest was defined as a plan to invest money in a new, unquoted venture, as indicated in business angels' descriptions of such plans. In order to increase reliability, we coded intention to invest as low or high, instead of using single option (Kerlinger and Lee, 1999). After repeat readings of the transcripts, we defined high intention to invest in those business angels who discussed past investment experience (including entrepreneurial experience), currently considered investments, and precise future investment plans.

As one business angel stated: "I'm based exclusively on proven attributes and experiences." Twelve business angels met these requirements. Low intention to invest was associated with eight business angels who discussed past investment experience and currently considered investments, and were open to the possibility of making an investment. Low intention to invest was exemplified by the business angel who stated: 'I'm focused on an exit strategy at this moment to get my money out. I wouldn't mind getting into new investment if good opportunity comes up."

Furthermore, we open-coded (Strauss and Corbin, 1998) all data that could be considered a reflection of business angels' decision-making values, attitudes toward risk, and predictions of future outcomes. We noted the frequent appearance of the word "information" in terms of information search, information exchange, valuable information, utilizing information, limited information, accurate information, and information-based planning. A few participants mentioned information exchange as a prerequisite for investing. For example, one interviewee stated: "Clearly being an effective communicator is critical. I talked to many angels before I started investing and learned from their best practices and experiences." Other open codes were created based on the meanings that emerged from the data. Table 1 summarizes the leading keywords in coding for alertness, regulatory focus, planning cognitive style, and risk propensity. 
Table 1: Main coding keywords from qualitative interviews

\begin{tabular}{|l|l|l|}
\hline Open code & Properties & Examples of participants'words \\
\hline $\begin{array}{l}\text { Seeking } \\
\text { information }\end{array}$ & $\begin{array}{l}\text { Being alert } \\
\text { Being active } \\
\text { Being aware of } \\
\text { opportunities } \\
\text { Being creative } \\
\text { Wanting to act }\end{array}$ & $\begin{array}{l}\text { Accurate information, search for information, } \\
\text { exchanging information, valuable information, } \\
\text { utilizing information, limited information; } \\
\text { Reduce uncertainty about that information; } \\
\text { Create value; } \\
\text { Seize opportunities }\end{array}$ \\
\hline Goal achievement & $\begin{array}{l}\text { Motivated } \\
\text { Being vigilant } \\
\text { Being eager } \\
\text { Sensitive }\end{array}$ & $\begin{array}{l}\text { Opportunities for gain, creating and accepting } \\
\text { new ideas; } \\
\text { Not make mistakes, feel secure; } \\
\text { Play to win, feel excited, learn things quickly; } \\
\text { How you feel when you succeed or fail }\end{array}$ \\
\hline $\begin{array}{l}\text { Implementation } \\
\text { intention }\end{array}$ & $\begin{array}{l}\text { Being analytical } \\
\text { Being conservative } \\
\text { Detailed explanation, interested in figures, } \\
\text { information-based planning, poor potential, } \\
\text { expected earning, detailed business plan; } \\
\text { Conservative approach }\end{array}$ \\
\hline $\begin{array}{l}\text { Operating in a } \\
\text { risky environment }\end{array}$ & Being aware of risk & $\begin{array}{l}\text { Risk-taking, risk-avoiding, uncertainty, } \\
\text { unrealistic expectations, very few business } \\
\text { plans highlight risk, confidence, risk analysis, } \\
\text { over-optimistic cash flow, challenge, } \\
\text { investment discipline, persistence }\end{array}$ \\
\hline
\end{tabular}

Source: Authors' calculation

Table 2 shows an analysis of the interview sample divided into the two groups of high and low intention to invest, along with coding frequencies. We found that all of the business angels interviewed exhibited entrepreneurial alertness in the terms of a proactive approach rooted in their different cognitive capacities and in other resources such as past investment and/or entrepreneurial experience, ability to process information, and goal expectations (Tang et al., 2012). Promotion focus enhances business angels' motivational strength toward investing by giving them a "subjective sense of importance to the activity" (Spiegel et al., 2004: 40) and consequently a stronger sense of engagement in the investment. Low planning in this early stage of the investment process indicates that business angels do not extensively think about or analyze possible barriers, such as poor investment quality or acceptable investment terms (Mason and Harrison, 2002b). Rather, they attach more value to optimistic forecasts of possible gains, demonstrating a high propensity for risk-taking. 
Table 2: Number of interviewees $(\mathrm{N}=20)$ according to their entrepreneurial alertness, regulatory focus, planning cognitive style, and risk propensity code, by level of intention (column percentages are shown)

\begin{tabular}{|l|r|r|}
\hline \multirow{2}{*}{\multicolumn{1}{|c|}{ VARIABLE }} & \multicolumn{2}{c|}{ INTENTION TO INVEST } \\
\cline { 2 - 3 } & LOW $(8 \mathrm{BA})$ & \multicolumn{1}{c|}{ HIGH (12 BA) } \\
\hline Entrepreneurial alertness low & $0(0 \%)$ & $0(0 \%)$ \\
\hline Entrepreneurial alertness high & $8(100 \%)$ & $12(100 \%)$ \\
\hline Prevention low & $0(0 \%)$ & $5(41.7 \%)$ \\
\hline Prevention high & $8(100 \%)$ & $7(58.3 \%)$ \\
\hline Planning low & $7(87.5 \%)$ & $9(75 \%)$ \\
\hline Planning high & $1(12.5 \%)$ & $3(25 \%)$ \\
\hline Promotion low & $7(87.5 \%)$ & $3(25 \%)$ \\
\hline Promotion high & $1(12.5 \%)$ & $9(75 \%)$ \\
\hline Risk propensity low & $7(87.5 \%)$ & $3(25 \%)$ \\
\hline Risk propensity high & $1(12.5 \%)$ & $9(75 \%)$ \\
\hline
\end{tabular}

Source: Authors' calculation

\subsection{Results from quantitative study and discussion}

Confirmatory factor analysis was conducted on the items representing the latent constructs (intent to invest, entrepreneurial alertness, regulatory focus, risk propensity) included in out conceptual model. Composite measures were calculated as averages of the items measuring the same construct; these were used in the statistical regression models. Due to multicollinearity, several multiple linear regression models were attempted, each with one entrepreneurial alertness dimension and planning cognitive style dimension. The significance level was set to $\alpha=0.05$, two-tailed. SPSS 23.0 and LISREL 8.80 were used for statistical analysis.

Multiple linear regression analysis was employed to test the relationships between entrepreneurial alertness, regulatory focus, planning cognitive style, risk propensity, and intention to invest. Control variables were considered but omitted from the final regression models due to a statistically non-significant relationship with intention to invest. In order to avoid multicollinearity, three regression models were considered, each with a separate entrepreneurial alertness measure (model 1-model 3), while other predictors and the dependent variable remained unchanged. Correlations between variables and descriptive statistics are summarized in Table 3. 
Table 3: Correlation matrix and descriptive statistics

\begin{tabular}{|c|c|c|c|c|c|c|c|c|c|c|c|c|}
\hline Dimension & $\mathrm{M}$ & $\mathrm{SD}$ & $\mathrm{P}$ & $\mathrm{SS}$ & $\mathrm{A}$ & $\mathrm{EJ}$ & $\mathrm{RP}$ & Pre & Pro & EE & US & INT \\
\hline P & 5.10 & 1.34 & 1 & & & & & & & & & \\
\hline SS & 5.61 & 1.32 & $0.49^{* *}$ & 1 & & & & & & & & \\
\hline AC & 5.55 & 1.4 & $0.39^{* *}$ & $0.79^{* *}$ & 1 & & & & & & & \\
\hline EJ & 5.03 & 1.26 & $0.49^{* *}$ & $0.72^{* *}$ & $0.70^{* *}$ & 1 & & & & & & \\
\hline RP & 3.96 & 1.30 & $-0.77^{* *}$ & $-0.28^{*}$ & -0.22 & $-0.34^{*}$ & 1 & & & & & \\
\hline Pre & 3.13 & 0.78 & -0.26 & $-0.58^{* *}$ & $-0.53^{* *}$ & $-0.45^{* *}$ & 0.18 & 1 & & & & \\
\hline Pro & 3.86 & 0.8 & $0.58^{* *}$ & $0.71^{* *}$ & $0.65^{* *}$ & $0.72^{* *}$ & $-0.45^{* *}$ & $-0.50^{* *}$ & 1 & & & \\
\hline EE & 0.01 & 0.75 & $-0.34^{*}$ & -0.05 & 0.01 & -0.08 & $0.31^{*}$ & 0.14 & -0.14 & 1 & & \\
\hline C & 0.47 & 0.5 & $-0.29^{*}$ & 0.12 & 0.01 & -0.08 & 0.20 & 0.01 & 0.13 & $0.31^{*}$ & 1 & \\
\hline INT & 3.93 & 1.29 & 0.25 & $0.62^{* *}$ & $0.56^{* *}$ & $0.57^{* *}$ & -0.15 & $-0.56^{* *}$ & $0.60^{* *}$ & 0 & 0.17 & 1 \\
\hline
\end{tabular}

Note: $\mathrm{P}=$ planning; $\mathrm{SS}=$ scanning and search; $\mathrm{AC}=$ association and connection; $\mathrm{EJ}=$ evaluation and judgment; $\mathrm{RP}=$ risk propensity; Pre = prevention; Pro = promotion; $\mathrm{EE}=$ entrepreneurial experience; $\mathrm{C}=$ country $(\mathrm{US}=1 ; \mathrm{EU}=0)$; INT = intention to invest; $\mathrm{M}=$ mean; $\mathrm{SD}=$ standard deviation; $n=55$

Source: Authors' calculation

The dimension of scanning and search in entrepreneurial alertness was included in the first model, association and connection dimension in the second model, and evaluation and judgment dimension in the third model. The hypotheses $(1 \mathrm{a} ; 1 \mathrm{~b} ; 1 \mathrm{c})$ suggested positive associations between the three dimensions of entrepreneurial alertness and intention to invest. Of the three dimensions of entrepreneurial alertness, only the scanning and search dimension had a statistically significant, positive relationship $(p=0.048)$ with intention to invest, when controlling for promotion focus, prevention focus, planning cognitive style, and risk propensity. The relationships between association and connection, or evaluation and judgment and intention to invest were not statistically significant. Therefore, the empirical evidence provided support for Hypothesis 1a.

Hypothesis 2 suggested a positive association between promotion regulatory focus and intention to invest. Promotion focus showed a positive effect on intention to invest in all three regression models, in which a specific dimension of entrepreneurial alertness was included as independent variable. Standardized regression coefficients were similar in all three models, ranging from 0.36 to 0.42 . Promotion focus showed a significant association with intention to invest, which provides support to Hypothesis 2. Hypothesis 3 suggested a positive association between prevention regulatory focus and intention to invest. Prevention focus had a marginally statistically significant, negative relationship $(p=0.067)$ with intention to invest in the first model (scanning and search dimension of alertness included), while the association in models 2 and 3 was statistically significant and negative. Based on the results we cannot support Hypothesis 3. 
Table 4: Factors associated with current investment intentions (results of multiple regression analysis)

\begin{tabular}{|l|c|c|c|}
\hline & $\begin{array}{c}\text { Model 1 } \\
\text { (EA-scanning } \\
\text { \& search) }\end{array}$ & $\begin{array}{c}\text { Model 2 } \\
\text { (EA-association } \\
\text { \& connection }\end{array}$ & $\begin{array}{c}\text { Model 3 } \\
\text { (evaluation } \\
\text { \& judgement) }\end{array}$ \\
\hline Dimension & Std. B (p-value) & Std. B (p-value) & Std. B (p-value) \\
\hline Scanning and search & $\mathbf{0 . 3 2}(\mathbf{0 . 0 4 8})$ & & \\
\hline $\begin{array}{l}\text { Association and } \\
\text { connection }\end{array}$ & & $0.19(0.205)$ & \\
\hline Evaluation and judgment & & & $0.26(0.097)$ \\
\hline Promotion focus & $0.36(0.027)$ & $\mathbf{0 . 4 2}(\mathbf{0 . 0 1 1})$ & $\mathbf{0 . 3 6}(\mathbf{0 . 0 3 6})$ \\
\hline Prevention focus & $-0.24(0.067)$ & $\mathbf{- 0 . 2 8}(\mathbf{0 . 0 2 9})$ & $\mathbf{- 0 . 3 ( 0 . 0 1 4 )}$ \\
\hline Planning cognitive style & $-0.18(0.323)$ & $-0.11(0.536)$ & $-0.12(0.486)$ \\
\hline Risk propensity & $0(0.985)$ & $0.04(0.801)$ & $0.05(0.737)$ \\
\hline $\mathrm{R}^{2}$ & 0.50 & 0.48 & 0.49 \\
\hline
\end{tabular}

Source: Authors' calculation

Hypothesis 4 suggested a positive association between planning cognitive style and intention to invest. We did not find significant association between the two when controlling for the effects of the other independent variables. Hypothesis 4 was not supported. Hypothesis 5 suggested a positive association between risk propensity and intention to invest. We found no statistically significant relationship between risk propensity and intention to invest when controlling for the effects of the other independent variables. Hypothesis 5 was not supported. In all three regression models, about $50 \%$ of the variance in business angels' intention to invest was explained by the independent variables included in the model. The results of the hypotheses testing are presented in Table 4.

\section{Results and discussion}

In this study, we have explored variables that contribute to the emergence of business angels' intention to invest to find that business angels' investment intentionality is driven by their regulatory focus orientation and their entrepreneurial alertness. Consistent with the theoretical expectations, business angels who are entrepreneurially alert demonstrate a stronger tendency to form an intention to invest. Furthermore, promotion-focused business angels seem to be more likely to form an intention to invest. Driven by promotion regulatory focus, business angels are more open and oriented toward the generation of new ideas and creativity (Tang et al., 2012). Additionally, promotion focus maintains a high motivation intensity level for alert scanning and search (Higgins and Cornwell, 2016). 
Although we hypothesized significant relationships between planning cognitive style and intention to invest, these were not supported empirically. This may be because of the role played by promotion focus in information processing at this early stage of the investment process when business angels are considering investment. Previous research on entrepreneurs (Baron, 1998) has shown that entrepreneurs use available decision heuristics in information processing (Higgins and King, 1981). Since promotion-focused business angels pay more attention to information that is compatible with their regulatory focus, promotion focus might serve as such a decision heuristic when business angels are forming an intention to invest. By aligning the benefits of perceived profit (i.e., their goal) with their promotion focus, they feel pleasure and associate positive attributes and potential outcomes with the investment (Aaker and Lee, 2001; Burmeister-Lamp et al., 2012). When this occurs, promotion focus prevails over planning cognitive style and decreases the angel's preference for rational analysis, instead reinforcing past experiences that have proven effective. It could be interesting to examine the moment in the investment process when business angels switch from heuristic information processing to a more analytical approach (Westhead et al., 2009). We expect that planning cognitive style moderates business angels' regulatory focus, depending on the investment stage, which is in line with Brockner's (2004) idea about alternation of regulatory foci for certain aspects of entrepreneurial process.

Furthermore, the results did not support our hypothesis that there would be a relationship between risk propensity and intention to invest. It may be that business angels' positive investment experiences in the past increase their propensity to take future risks. Business angels are able to process current information through the schemas identified in previous experiences, which in turn affect their risk perception (reducing perceived risk). In addition, business angels with promotion regulatory focus tend to take higher risks (i.e., have a higher risk propensity). Compared to risk propensity, regulatory focus is a more salient driver of investment behavior, as business angels use a stronger eagerness strategy to secure potential gains (Bryant and Dunford, 2008). Moreover, if investment is framed positively (Kahneman and Tversky, 1979) and success is expected, business angels develop higher risk propensity, since the propensity for risk is a situational characteristic that can develop over time (Bryant and Dunford, 2008).

By emphasizing the role of business angels' promotion focus on forming an intention to invest, these results add to the body of knowledge on regulatory focus. Furthermore, this research contributes to the entrepreneurial alertness literature by highlighting the role of the scanning and search dimension as it relates to investment intentions. Our predictions that were empirically supported emphasize the importance of the cognitive and self-regulatory processes specific to the early stage of the investment process. For example, a study conducted by Cox et al. (2017) investigated "the investment paradox" (i.e., why attractive new ventures exhibit relatively poor 
investment potential). These authors found that the "entrepreneur $\llcorner$ angel fit" (i.e., the match between the lead entrepreneur's educational background and the previous industry experience of the business angel) influences angels' evaluation of the firm's potential. Such findings indicate that cognitive and self-regulatory processes are an important element in investment decision-making and should be considered alongside others because they can significantly modify angels' perception of fundamental investment criteria, regardless of the attractiveness of those criteria.

The practical implication of this research is related to establishing a better fit in the angel-entrepreneur dyad. Because both entrepreneurial alertness and regulatory focus are unique individual characteristics, there will be interaction between the business angel's and the entrepreneur's characteristics. Entrepreneurs and investors are alert to business opportunities and scan and search for specific kinds of information that fit with their regulatory focus. Accordingly, an investment can be perceived as promotion- or prevention-focused, depending on how it is presented. An investment that is presented as profitable, innovative, or profitoriented is drawing on promotion-focused information, whereas an investment that is presented as risk- or loss-averse or uncertain in its outcome is communicating prevention-focused information (Halvorson and Higgins, 2013). Such motivational language can be learned. This suggests that both an entrepreneur in search of finance and a business angel in search of an investment opportunity should be ready to accommodate the other's regulatory focus by providing information that will meet mutual expectations. In the end, as Halvorson and Higgins (2013) stated, the improved entrepreneur-investor dyad fit increases trust, confidence, engagement, and value. Furthermore, as regulatory focus can be situationally provoked, learning could include simulations aimed at encouraging entrepreneurs to become more entrepreneurially alert and promotion-oriented when pitching to investors, and encouraging business angels to become interested in investing (Avnet and Higgins, 2003; Amato et al., 2016).

This study found that business angels' intention to invest depends on individual-level characteristics. Since intention formation is an iterative process that emerges and develops, future research could further examine these relationships by investigating how self-efficacy impacts the perceived feasibility (Fitzsimmons and Douglas, 2011) of the investment and thus business angels' intentionality. For example, when the perceived feasibility of the investment is high, business angels may be more likely to make an investment. Business angels' willingness to make investments can lead to a greater value for entrepreneurs, the angels themselves, and society.

This study is not without its limitations. First, the analysis is based on selfreport data provided by business angels; such data are limited by the extent to which participants have insight into their motivational state and experiences (Summerville and Roese, 2008). Future research can extend these findings by using different research methods (e.g., experimental). In addition, a longitudinal 
research design could study whether angels' intention to invest actually leads to investment behavior. Given the importance of the entrepreneurial alertness construct and the questions surrounding its role in entrepreneurial incentives (McCaffrey, 2014), a longitudinal design could provide insight into all three entrepreneurial alertness components. Such a design would shed light on the alertness dimensions as stages in the investment process, rather than as individual traits captured at a given moment in time (Amato et al., 2016). In parallel, regulatory focus could be investigated to confirm whether it is dispositional or situationally induced (Avnet and Higgins, 2003) depending on the objective of the particular investment stage.

Second, one could criticize the small size of both samples used in this study. Because business angels are largely an invisible population, robust random sampling is a challenge (Harrison and Mason, 2007). Indeed, the meager size of the total population of business angels represents a major barrier to the development of information about their behavior. Although improvements to the study, such as gaining larger samples, would have been welcome, nevertheless, reliable and valid measurement scales were used and the simplest correlation analysis was conducted. Therefore, despite these limitations, the results of this mixed methods study provide some initial insights into business angels' cognitive dynamics when making investment decisions. As we noted above, our data set may also suffer from self-selection bias, and survivor's bias in relation to business angels included. In the data set we were also not able to control for different structure of business angels' investments depending on industries and expertise or markets they cover.

In conclusion, one major gap in the study of entrepreneurial intention has been the failure to connect the individual characteristics of entrepreneurs to actual behaviors (Hmieleski and Corbett, 2006). This research bridges this gap by linking the role of regulatory focus and entrepreneurial alertness to the formation of business angels' investment intentions. The findings shed light on the individual differences among business angels that facilitate their intention to invest.

\section{Conclusions}

This study explored factors that contribute to the emergence of business angels' intention to invest to find that business angels' investment intentionality is driven by their regulatory focus orientation and their entrepreneurial alertness. We find that, business angels who are entrepreneurially alert, consistent with the theoretical expectations, demonstrate a stronger tendency to form an intention to invest. Also, promotion-focused business angels seem to be more likely to form an intention to invest. On the other hand, we couldn't find significant relationships between planning cognitive style and intention to invest, these were not supported 
empirically. Furthermore, the results did not support our hypothesis that there would be a relationship between risk propensity and intention to invest. This research contributes to the entrepreneurial alertness literature by highlighting the role of the scanning and search dimension as it relates to investment intentions. The practical implication of this research is related to establishing a better fit in the angel-entrepreneur dyad. One of the findings relates to the fact that business angels' intention to invest depends on individual-level characteristics.

This study is not without its limitations. First, the analysis is based on self-report data provided by business angels; such data are limited by the extent to which participants have insight into their motivational state and experiences. Future research can extend these findings by using different research methods (e.g., experimental). In addition, a longitudinal research design could study whether angels' intention to invest actually leads to investment behavior. In parallel, regulatory focus could be investigated as well. One of the relevant issues is the small size of both samples used in this study. However, despite these limitations, we believe that the results of this mixed methods study provide some initial insights into business angels' cognitive dynamics when making investment decisions. One major gap in the study of entrepreneurial intention has been the failure to connect the individual characteristics of entrepreneurs to actual behaviors. This research bridges this gap by linking the role of regulatory focus and entrepreneurial alertness to the formation of business angels' investment intentions. The findings shed light on the individual differences among business angels that facilitate their intention to invest.

\section{References}

Aaker, J. L., Lee, A. Y. (2001) “'I' Seek Pleasures and 'We' Avoid Pains: The Role of Self-Regulatory Goals in Information Processing and Persuasion", Journal of Consumer Research, Vol. 28, No. 1, pp. 33-49, doi: 10.1086/321946.

Ajzen, I. (1991) "The Theory of Planned Behavior", Organizational Behavior and Human Decision Processes, Vol. 50, No. 2, pp. 179-211, doi: 10.1016/07495978(91)90020-t.

Alvarez, S. A., Barney, J. B. (2007) "Discovery and Creation: Alternative Theories of Entrepreneurial Action", Strategic Entrepreneurship Journal, Vol. 1, No. 1-2, pp. 11-26, doi: 10.15603/1982-8756/roc.v3n6p123-152.

Amato, C. et al. (2016) "Regulatory Modes and Entrepreneurship: The Mediational Role of Alertness in Small Business Success", Journal of Small Business Management, Advance online publication, doi: 10.1111/jsbm.12255.

Armstrong, J. S., Overton, T. S. (1977) "Estimating Nonresponse Bias in Mail Surveys", Journal of Marketing Research, Vol. 14, No. 3, pp. 396-402, doi: $10.2307 / 3150783 \mathrm{~h}$. 
Avnet, T., Higgins, E. T. (2003) "Locomotion, Assessment, and Regulatory Fit: Value Transfer from 'How' to 'What", Journal of Experimental Social Psychology, Vol. 39, No. 5, pp. 525-530, doi: 10.1016/s0022-1031(03)00027-1.

Barbosa, S. D., Gerhardt, M. W., Kickul, J. R. (2007) "The Role of Cognitive Style and Risk Preference on Entrepreneurial Self-Efficacy and Entrepreneurial Intentions", Journal of Leadership \& Organizational Studies, Vol. 13, No. 4, pp. 86-104, doi: 10.1177/10717919070130041001.

Baron, R. A. (1998) "Cognitive Mechanisms in Entrepreneurship: Why and When Entrepreneurs Think Differently than Other People", Journal of Business Venturing, Vol. 13, No. 4, pp. 275-294, doi: 10.1016/S0883-9026(97)00031-1.

Baron, R. A. (2006) "Opportunity Recognition as Pattern Recognition: How Entrepreneurs 'Connect the Dots' to Identify New Business Opportunities", The Academy of Management Perspectives, Vol. 20, No. 1, pp. 104-119, doi: 10.5465/ amp.2006.19873412.

Boyd, N. G., Vozikis, G. S. (1994) "The Influence of Self-Efficacy on the Development of Entrepreneurial Intentions and Actions", Entrepreneurship Theory and Practice, Vol. 18, pp. 63-77, doi: 10.1177/104225879401800404.

Brislin, R. W. (1970) "Back-Translation for Cross-Cultural Research", Journal of CrossCultural Psychology, Vol. 1, No. 3, pp. 185-216, doi: 10.1177/135910457000100301.

Brockner, J., Higgins, E. T., Low, M. B. (2004) "Regulatory Focus Theory and the Entrepreneurial Process", Journal of Business Venturing, Vol. 19, No. 2, pp. 203-220, doi: 10.1016/s0883-9026(03)00007-7h.

Bryant, P., Dunford, R. (2008) "The Influence of Regulatory Focus on Risky Decision-Making", Applied Psychology, Vol. 57, No. 2, pp. 335-359, doi: 10.1111/j.1464-0597.2007.00319.x.

Bryman, A. (2006) "Integrating Quantitative and Qualitative Research: How Is It Done?" Qualitative Research, Vol. 6, No. 1, pp. 97-113, doi: 10.1177/ 1468794106058877.

Burmeister-Lamp, K., Lévesque, M., Schade, C. (2012) “Are Entrepreneurs Influenced by Risk Attitude, Regulatory Focus or Both? An Experiment on Entrepreneurs' Time Allocation", Journal of Business Venturing, Vol. 27, No. 4, pp. 456-476, doi: 10.1016/j.jbusvent.2011.12.001.

Chen, C. C., Greene, P. G., Crick, A. (1998) "Does Entrepreneurial Self-Efficacy Distinguish Entrepreneurs from Managers?", Journal of Business Venturing, Vol. 13, No. 4, pp. 295-316, doi: 10.1016/s0883-9026(97)00029-3.

Cools, E., Van den Broeck, H. (2007) "Development and Validation of the Cognitive Style Indicator", The Journal of Psychology, Vol. 141, No. 4, pp. 359-387, doi: 10.3200/jrlp.141.4.359-388.

Cox, K. C., Lortie, J., Gramm, K. (2017) “The Investment Paradox: Why Attractive New Ventures Exhibit Relatively Poor Investment Potential”, Venture Capital, Advance online publication, doi: 10.1080/13691066.2016.1247982. 
Creswell, J. W. (2003) Research Design: Qualitative, Quantitative, and Mixed Methods Approaches, $2^{\text {nd }}$ ed, Thousand Oaks, CA: Sage.

Crowe, E., Higgins, E. T. (1997) "Regulatory Focus and Strategic Inclinations:

Promotion and Prevention in Decision-Making", Organizational Behavior and Human Decision Processes, Vol. 69, No. 2, pp. 117-132, doi: 10.1006/obhd. 1996.2675.

Davidsson, P. (2003) "The Domain of Entrepreneurship Research: Some Suggestions", Advances in Entrepreneurship, Firm Emergence and Growth, Vol. 6, No. 3, pp. 315-372, doi: 10.1016/s1074-7540(03)06010-0h.

Dimov, D. (2007) "From Opportunity Insight to Opportunity Intention: The Importance of Person-Situation Learning Match", Entrepreneurship Theory and Practice, Vol. 31, No. 4, pp. 561-583, doi: 10.1111/j.1540-6520.2007.00188.x.

Fitzsimmons, J. R., Douglas, E. J. (2011) "Interaction Between Feasibility and

Desirability in the Formation of Entrepreneurial Intentions", Journal of Business Venturing, Vol. 26, No. 4, pp. 431-440, doi: 10.1016/j.jbusvent. 2010.01.001.

Foo, M. D., Uy, M. A., Murnieks, C. (2015) "Beyond Affective Valence: Untangling Valence and Activation Influences on Opportunity Identification", Entrepreneurship Theory and Practice, Vol. 39, No. 2, pp. 407-431, doi: 10.1111/ etap.12045.

Forlani, D., Mullins, J. W. (2000) "Perceived Risks and Choices in Entrepreneurs' New Venture Decisions", Journal of Business Venturing, Vol. 15, No. 4, pp. 305-322, doi: 10.1016/s0883-9026(98)00017-2h.

Gielnik, M. M. et al. (2014) "Antecedents of Business Opportunity Identification and Innovation: Investigating the Interplay of Information Processing and Information Acquisition", Applied Psychology, Vol. 63, No. 2, pp. 344-381, doi: 10.1111/j.1464-0597.2012.00528.x.

Greene, J. C. (2007) Mixed Methods in Social Inquiry, Vol. 9, San Francisco, CA: John Wiley \& Sons.

Halvorson, H. G., Higgins, E. T. (2013) Focus: Use Different Ways of Seeing the World for Success and Influence, New York: Penguin.

Harrison, R. T., Mason, C. M. (2007) "Does Gender Matter? Women Business Angels and the Supply of Entrepreneurial Finance", Entrepreneurship Theory and Practice, Vol. 31, No. 3, pp. 445-472, doi: 10.1111/j.1540-6520.2007. 00182.x.

Higgins, E. T. (1997) "Beyond Pleasure and Pain”, American Psychologist, Vol. 52, No. 12, pp. 1280-1300, doi: 10.1037/0003-066x.52.12.1280.

Higgins, E. T. (1998) "Promotion and Prevention: Regulatory Focus as a Motivational Principle", Advances in Experimental Social Psychology, Vol. 30, pp. 1-46, doi: 10.1016/s0065-2601(08)60381-0. 
Higgins, E. T., Cornwell, J. F. M. (2016) "Securing Foundations and Advancing Frontiers: Prevention and Promotion Effects on Judgment and Decision Making”, Organizational Behavior and Human Decision Processes, Vol. 136, pp. 56-67, doi: 10.1016/j.obhdp.2016.04.005.

Higgins, E. T., King, G. A. (1981) "Accessibility of Social Constructs: InformationProcessing Consequences of Individual and Contextual Variability". In Cantor

N., Kihlstrom J. F. eds., Personality, Cognition, and Social Interaction, Hillsdale, NJ: Erlbaum.

Higgins, E. T. et al. (2001) "Achievement Orientations from Subjective Histories of Success: Promotion Pride Versus Prevention Pride", European Journal of Social Psychology, Vol. 31, No. 1, pp. 3-23, doi: 10.1002/ejsp.27.

Hmieleski, K. M., Baron, R. A. (2008) "Regulatory Focus and New Venture Performance: A Study of Entrepreneurial Opportunity Exploitation under Conditions of Risk Versus Uncertainty", Strategic Entrepreneurship Journal, Vol. 2, No. 4, pp. 285-299, doi: 10.1002/sej.56.

Hmieleski, K. M., Corbett, A. C. (2006) "Proclivity for Improvisation as a Predictor of Entrepreneurial Intentions", Journal of Small Business Management, Vol. 44, No. 1, pp. 45-63, doi: 10.1111/j.1540-627x.2006.00153.x.

Johnson, R. B., Onwuegbuzie, A. (2004) "Mixed Methods Research: A Research Paradigm Whose Time Has Come", Educational Researcher, Vol. 33, pp. 14 26, doi: 10.3102/0013189x033007014.

Johnson, R. B., Onwuegbuzie, A. J., Turner, L. A. (2007) "Toward a Definition of Mixed Methods Research", Journal of Mixed Methods Research, Vol. 1, No. 2 , pp. 112-133, doi: 10.1177/1558689806298224.

Kahneman, D., Tversky, A. (1979) "Prospect Theory: An Analysis of Decision under Risk", Econometrica: Journal of the Econometric Society, Vol. 42, No. 2, pp. 263-291, doi: 10.21236/ada045771.

Kaish, S., Gilad, B. (1991) "Characteristics of Opportunities Search of Entrepreneurs Versus Executives: Sources, Interests, General Alertness", Journal of Business Venturing, Vol. 6, No. 1, pp. 45-61, doi: 10.1016/0883-9026(91)90005-x.

Keh, H. T., Foo, M. D., Lim, B. C. (2002) "Opportunity Evaluation under Risky Conditions: The Cognitive Processes of Entrepreneurs", Entrepreneurship Theory and Practice, Vol. 27, No. 2, pp. 125-148, doi: 10.1111/1540-8520. 00003.

Kerlinger, F., Lee, H. (1999) Foundations of Behavioral Research, Belmont, CA: Wadsworth Publishing.

Kirzner, I. M. (1979) Perception, Opportunity, and Profit: Studies in the Theory of Entrepreneurship, Chicago: University of Chicago Press.

Kozhevnikov, M., Evans, C., Kosslyn, S. M. (2014) "Cognitive Style as Environmentally Sensitive Individual Differences in Cognition a Modern Synthesis and Applications in Education, Business, and Management", 
Psychological Science in the Public Interest, Vol. 15, No. 1, pp. 3-33, doi: $10.1177 / 1529100614525555$.

Krueger Jr, N., Kickul, J. (2006) "So You Thought the Intentions Model Was Simple? Navigating the Complexities and Interactions of Cognitive Style, Culture, Gender, Social Norms, and Intensity on the Pathways to Entrepreneurship". Paper presented at the USASBE conference, Tucson, Arizona, doi: 10.2139/ssrn.1150881.

Krueger Jr, N. F., Reilly, M. D., Carsrud, A. L. (2000) "Competing Models of Entrepreneurial Intentions", Journal of Business Venturing, Vol. 15, No. 5, pp. 411-432, doi: 10.1016/s0883-9026(98)00033-0h.

Lindsay, N. J. (2004) "Do Business Angels Have an Entrepreneurial Orientation?", Venture Capital, Vol. 6, No. 2-3, pp. 197-210, doi: 10.1080/13691060420001675983.

Mason, C. M. (2006) "Informal Sources of Venture Finance". In Parker, S. C. ed., The Life Cycle of Entrepreneurial Ventures, New York: Springer.

Mason, C. M., Botelho, T. (2014) The 2014 Survey of Business Angel Investing in the UK: A Changing Market Place, Glasgow: University of Glasgow, Adam Smith Business School.

Mason, C., Botelho, T., Harrison, R. (2016) "The Transformation of the Business Angel Market: Empirical Evidence and Research Implications", Venture Capital, Vol. 18, No. 4, pp. 321-344, doi: 10.1080/13691066.2016.1229470.

Mason, C., Botelho, T., Zygmunt, J. (2017) "Why Business Angels Reject Investment Opportunities: Is It Personal?", International Small Business Journal, Vol. 35, No. 5, pp. 519-534, doi: 10.1177/0266242616646622h.

Mason, C. M., Harrison, R. T. (2002a) "Is it Worth it? The Rates of Return from Informal Venture Capital Investments", Journal of Business Venturing, Vol. 17, No. 3, pp. 211-236, doi: 10.1016/s0883-9026(00)00060-4.

Mason, C. M., Harrison, R. T. (2002b) "Barriers to Investment in the Informal Venture Capital Sector", Entrepreneurship \& Regional Development, Vol. 14, No. 3, pp. 271-287, doi: 10.1080/08985620210142011.

Mason, C. M., Harrison, R. T. (2008) "Measuring Business Angel Investment Activity in the United Kingdom: A Review of Potential Data Sources", Venture Capital, Vol. 10, No. 4, pp. 309-330, doi: 10.1080/13691060802380098.

Maxwell, A. L., Jeffrey, S. A., Lévesque, M. (2011) "Business Angel Early Stage Decision Making”, Journal of Business Venturing, Vol. 26, No. 2, pp. 212-225, doi: 10.1016/j.jbusvent.2009.09.002h.

McCaffrey, M. (2014) "On the Theory of Entrepreneurial Incentives and Alertness", Entrepreneurship Theory and Practice, Vol. 38, No. 4, pp. 891-911, doi: 10.1111/ etap. 12013.

McMullen, J. S., Shepherd, D. A. (2002) "Regulatory Focus and Entrepreneurial Intention: Action Bias in the Recognition and Evaluation of Opportunities". In 
Bygrave, W. D. ed., Frontiers of Entrepreneurship Research, Wellesley, MA: Babson College.

McMullen, J. S., Shepherd, D. A. (2006) "Entrepreneurial Action and the Role of Uncertainty in the Theory of the Entrepreneur", Academy of Management Review, Vol. 31, No. 1, pp. 132-152, doi: 10.4337/9781783479801.00007.

Mitteness, C., Sudek, R., Cardon, M. S. (2012) “Angel Investor Characteristics that Determine Whether Perceived Passion Leads to Higher Evaluations of Funding Potential", Journal of Business Venturing, Vol. 27, No. 5, pp. 592-606, doi: 10.1016/j.jbusvent.2011.11.003h.

Moen, Ø., Sørheim, R., Erikson, T. (2008) "Born Global Firms and Informal Investors: Examining Investor Characteristics", Journal of Small Business Management, Vol. 4, No. 4, pp. 536-549, doi: 10.1111/j.1540-627x.2008.00255. xh.

Palich, L. E., Ray Bagby, D. (1995) "Using Cognitive Theory to Explain Entrepreneurial Risk-Taking: Challenging Conventional Wisdom", Journal of Business Venturing, Vol. 10, No. 6, pp. 425-438, doi: 10.1016/08839026(95)00082-j.

Shane, S. A. (2003) A General Theory of Entrepreneurship: The IndividualOpportunity Nexus, Cheltenham, UK: Edward Elgar.

Shirokova, G., Osiyevskyy, O., Bogatyreva, K. (2016) "Exploring the IntentionBehavior Link in Student Entrepreneurship: Moderating Effects of Individual and Environmental Characteristics", European Management Journal, Vol. 34, No. 4, pp. 386-399, doi: 10.1016/j.emj.2015.12.007.

Sitkin, S. B., Pablo, A. L. (1992) "Reconceptualizing the Determinants of Risk Behavior", Academy of Management Review, Vol. 17, No. 1, pp. 9-38, doi: 10.5465/amr.1992.4279564h.

Sitkin, S. B., Weingart, L. R. (1995) "Determinants of Risky Decision-Making Behavior: A Test of the Mediating Role of Risk Perceptions and Propensity", Academy of Management Journal, Vol. 38, No. 6, pp. 1573-1592, doi: 10.5465/ 256844.

Spiegel, S., Grant-Pillow, H., Higgins, E. T. (2004) "How Regulatory Fit Enhances Motivational Strength During Goal Pursuit", European Journal of Social Psychology, Vol. 34, No. 1, pp. 39-54, doi: 10.1002/ejsp.180.

Stewart, W. H., May, R. C., Kalia, A. (2008) "Environmental Perceptions and Scanning in the United States and India: Convergence in Entrepreneurial Information Seeking", Entrepreneurship Theory and Practice, Vol. 32, No. 1, pp. 83-106, doi: 10.1111/j.1540-6520.2007.00217.x.

Strauss, A., Corbin, J. (1998) Basics of Qualitative Research: Procedures and Techniques for Developing Grounded Theory, 2nd edition, Thousand Oaks, CA: Sage. 
Summerville, A., Roese, N. J. (2008) "Self-Report Measures of Individual Differences in Regulatory Focus: A Cautionary Note", Journal of Research in Personality, Vol. 42, No. 1, pp. 247-254, doi: 10.1016/j.jrp.2007.05.005.

Tang, J. (2008) "Environmental Munificence for Entrepreneurs: Entrepreneurial Alertness and Commitment", International Journal of Entrepreneurial Behavior \& Research, Vol. 14, No. 3, pp. 128-151, doi: 10.1108/13552550810874664.

Tang, J., Kacmar, K. M., Busenitz, L. (2012) "Entrepreneurial Alertness in the Pursuit of New Opportunities", Journal of Business Venturing, Vol. 27, No. 1, pp. 77-94, doi: 10.1016/j.jbusvent.2010.07.001h.

Tumasjan, A., Braun, R. (2012) "In the Eye of the Beholder: How Regulatory Focus and Self-Efficacy Interact in Influencing Opportunity Recognition", Journal of Business Venturing, Vol. 27, No. 6, pp. 622-636, doi: 10.2139/ssrn.1927078.

Valliere, D. (2013) "Towards a Schematic Theory of Entrepreneurial Alertness", Journal of Business Venturing, Vol. 28, No. 3, pp. 430-442, doi: 10.1016/j. jbusvent.2011.08.004.

Venkatraman, N. (1989) "Strategic Orientation of Business Enterprises: The Construct, Dimensionality, and Measurement", Management Science, Vol. 35, No. 8, pp. 942-962, doi: 10.1287/mnsc.35.8.942h.

Westhead, P., Ucbasaran, D., Wright, M. (2009) "Information Search and Opportunity Identification: The Importance of Prior Business Ownership Experience", International Small Business Journal, Vol. 27, No. 6, pp. 659680, doi: 10.1177/0266242609344255.

Wetzel, W. E. (1983) “Angels and Informal Risk Capital”, Sloan Management Review, Vol. 24, No. 4, pp. 23-34.

White, B. A., Dumay, J. (2017) "Business Angels: A Research Review and New Agenda", Venture Capital, Vol. 19, No. 3, pp. 183-216, doi: 10.1080/13691066.2017. 1290889.

Wiltbank, R. et al. (2009) "Prediction and Control under Uncertainty: Outcomes in Angel Investing", Journal of Business Venturing, Vol. 24, No. 2, pp. 116-133, doi: 10.1016/j.jbusvent.2007.11.004.

Witkin, H. A. et al. (1977) "Field-Dependent and Field-Independent Cognitive Styles and Their Educational Implications", Review of Educational Research, Vol. 47, No. 1, pp. 1-64, doi: 10.2307/1169967.

Wolf, E. J. et al. (2013) "Sample Size Requirements for Structural Equation Models an Evaluation of Power, Bias, and Solution Propriety", Educational and Psychological Measurement, Vol. 73, No. 6, pp. 913-934, doi: 10.1177/ 0013164413495237.

Zhang, P., Cain, K. W. (2017) "Reassessing the Link Between Risk Aversion and Entrepreneurial Intention: The Mediating Role of the Determinants of Planned Behavior", International Journal of Entrepreneurial Behavior \& Research, Advance online publication, doi: 10.1108/IJEBR-08-2016-0248. 


\title{
Poslovni anđeli i mehanizmi koji ih podupiru u namjeri investiranja
}

\author{
Mateja Drnovšek ${ }^{1}$, Sanda Franić ${ }^{2}$, Alenka Slavec ${ }^{3}$
}

\begin{abstract}
Sažetak
U ovom se istraživanju koristimo teorijom regulatornog fokusa kako bismo istražili kognitivne mehanizme koji podupiru poslovne anđele u namjeri investiranja. Iako su prijašnja istraživanja pokazala da su percipirana poželjnost $i$ percipirana izvedivost planiranog ponašanja dva najvažnija prethodnika poduzetnikova planiranog ponašanja, malo je poznato što prethodi planiranom ponašanju poslovnih anđela. Ovu prazninu popunjavamo povezujući uloge regulatornog fokusa i poduzetničke budnosti u stvaranju namjere investiranja. Započinjemo prikupljanjem kvalitativnih podataka putem polu-strukturiranih intervjua $s$ poslovnim anđelima kako bismo dobili širi uvid u planirano ponašanje poslovnih anđela, njihove ciljeve, planiranje te ostale značajke vezane uz njihove spoznajne procese. Prikupili smo i podatke dobivene anketiranjem međunarodnog uzorka poslovnih anđela kako bismo pokazali da poduzetnička budnost, preciznije njezino svojstvo skeniranja i pretraživanja imaju važnu ulogu u budućim namjerama. Osim toga, poslovni anđeli s promotivnim fokusom skloniji su investiranju.
\end{abstract}

Ključne riječi: namjera investiranja, poduzetnička budnost, regulatorni fokus, kognitivni stil, sklonost riziku

JEL klasifikacija: D81

${ }^{1}$ Redoviti profesor, Ekonomski fakultet, Sveučilište u Ljubljani, Katedra za poduzetništvo (pročelnik Katedre), Kardeljeva pl. 17, Ljubljana, Slovenija. Znanstveni interes: psihologija poduzetnika, akademsko poduzetništvo. Tel.: +38615892 613. E-mail: mateja.drnovsek@ ef.uni-lj.si. Web stranica: www.ef.uni-lj.si (osoba za kontakt).

2 Doktorand, Ekonomski fakultet, Sveučilište u Ljubljani, Kardeljeva pl. 17, Ljubljana, Slovenija. Znanstveni interes: psihologija poslovnih anđela.E-mail: sanda.franic@mst-intersped.hr.

${ }^{3}$ Docent, Ekonomski fakultet, Sveučilište u Ljubljani, Katedra za poduzetništvo (pročelnik Katedre), Kardeljeva pl. 17, Ljubljana, Slovenija. Znanstveni interes: psihologija poduzetnika, financiranje u poduzetništvu.Tel.: + 38615892 613.E-mail: alenka.slavec@ef.uni-lj.si.Web stranica: www.ef.uni-lj.si. 


\section{Appendix A. Semi-structured interview questions}

1. What was your motivation to become a business angel?

2. Where do you usually acquire information about potential opportunities to invest in?

3. What is your own attitude toward risky and uncertain outcomes when making decision to invest?

4. What is your own attitude toward decision to invest when you dispose with limited information and limited time to decide?

5. What is your own attitude toward decision to invest when you have a gut feeling for potential opportunity?

6. How do you usually behave when you make a decision to invest: do you rely on your instincts, your past investment/entrepreneurial experience, or do you do detailed analysis before making a decision to invest?

7. How important is your entrepreneurial experience to you when you make a decision to invest?

8. When facing multiple opportunities to invest, how do you make a decision in selecting the good one?

9. What is your own attitude toward pursuing future gains, versus preventing future losses when making a decision to invest?

10. How do you define goals for yourself when you make decisions to invest?

11. What added value do you usually bring to investment when making decision to invest?

12. Is there anything else you would like to add as you think it is important for investment decision-making? 


\section{Appendix B: Measurement models}

Appendix B1: Measurement model of intention to invest (CEI).

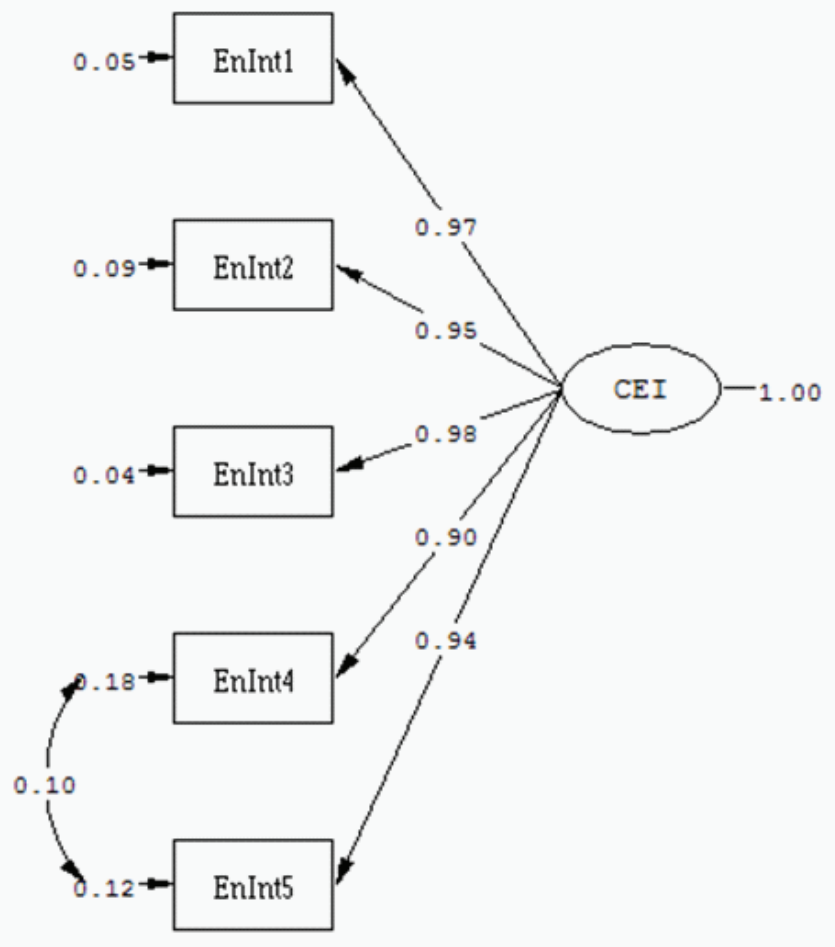

Chi-Square $=5.15, \mathrm{df}=4, \mathrm{p}-\mathrm{value}=0.27197, \mathrm{RMSEA}=0.073$ 
Appendix B2: Measurement model of entrepreneurial alertness.

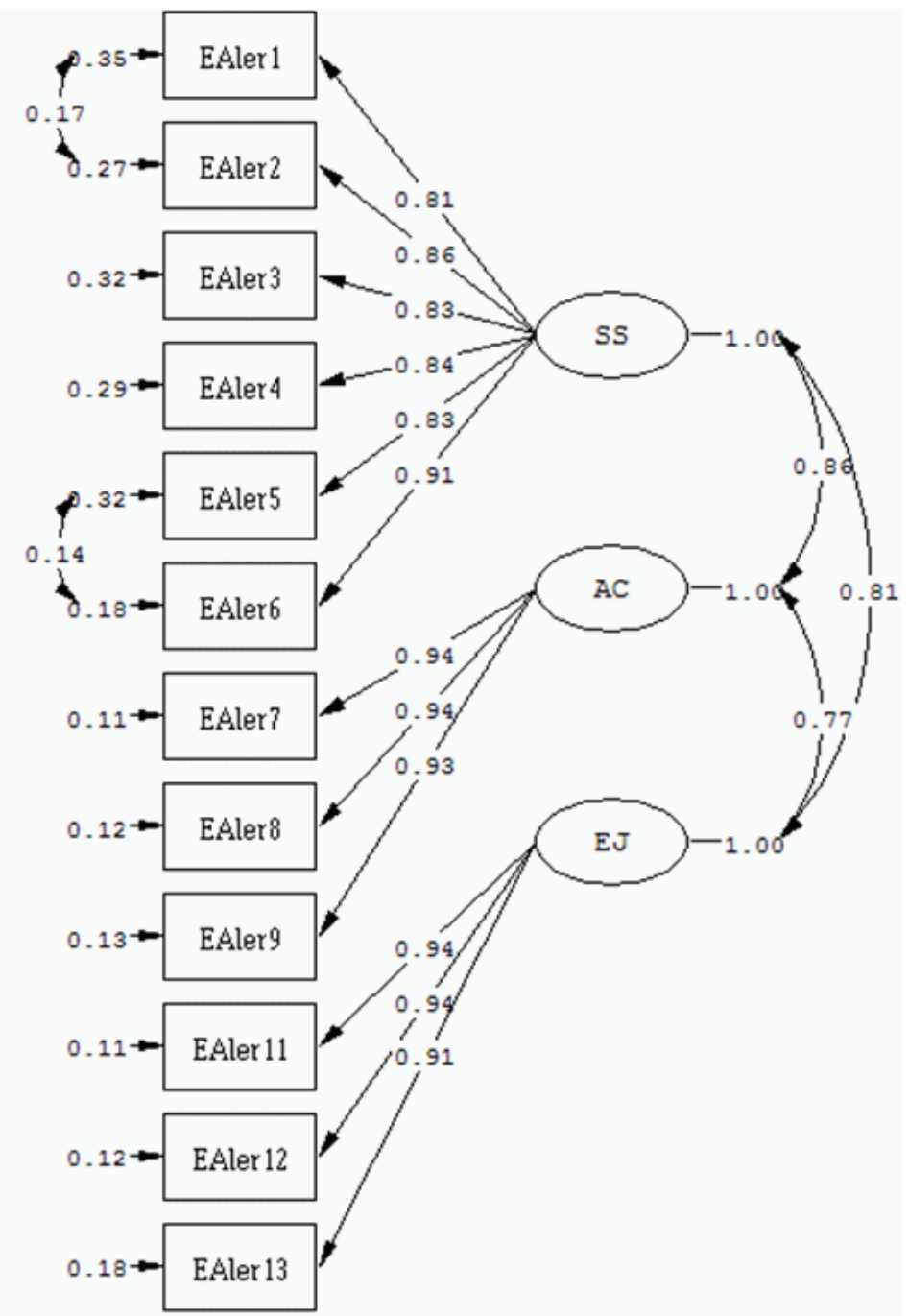

Chi-Square $=59.45, d f=49, P-$ value $=0.14570$, RMSEA $=0.050$ 
Appendix B3: Measurement model of risk propensity.

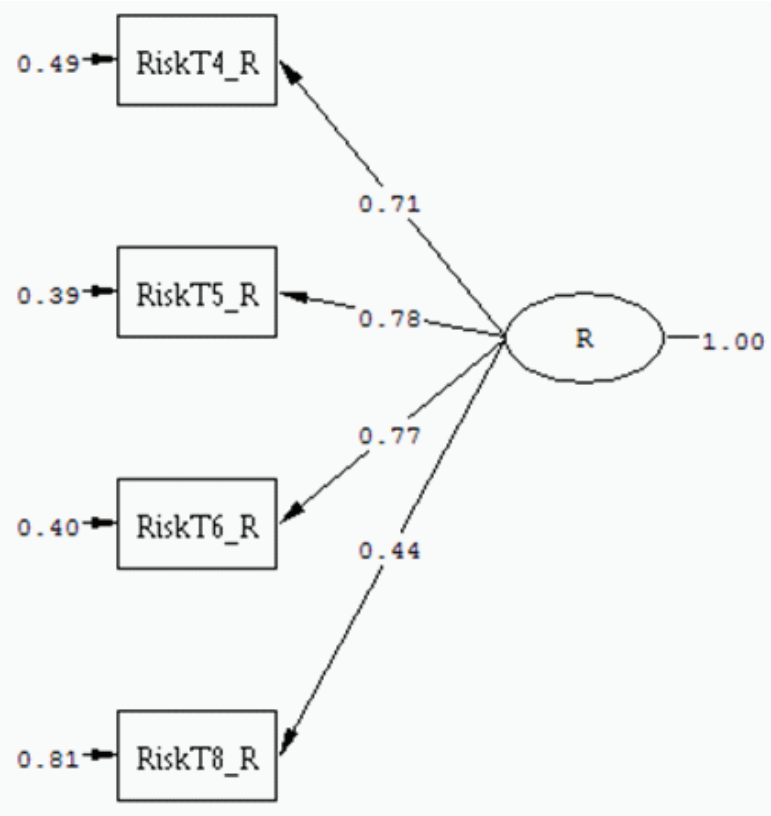

Chi-Square $=2.13, \mathrm{df}=2, \mathrm{P}-\mathrm{value}=0.34553, \mathrm{RMSEA}=0.030$ 
Appendix B4: Measurement model of promotion and prevention foci.

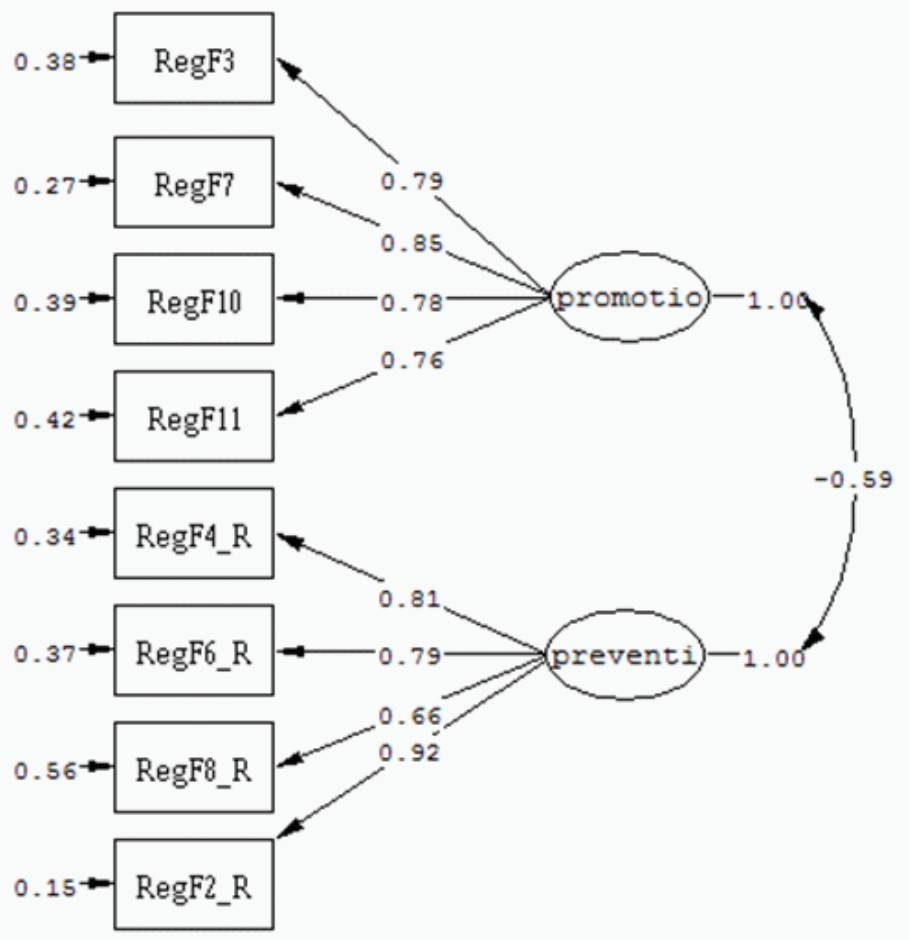

Chi-Square=25.63, $d f=19, \mathrm{p}-\mathrm{value}=0.14086, \mathrm{RMSEA}=0.080$ 
Appendix B5: Measurement model of planning cognitive style.

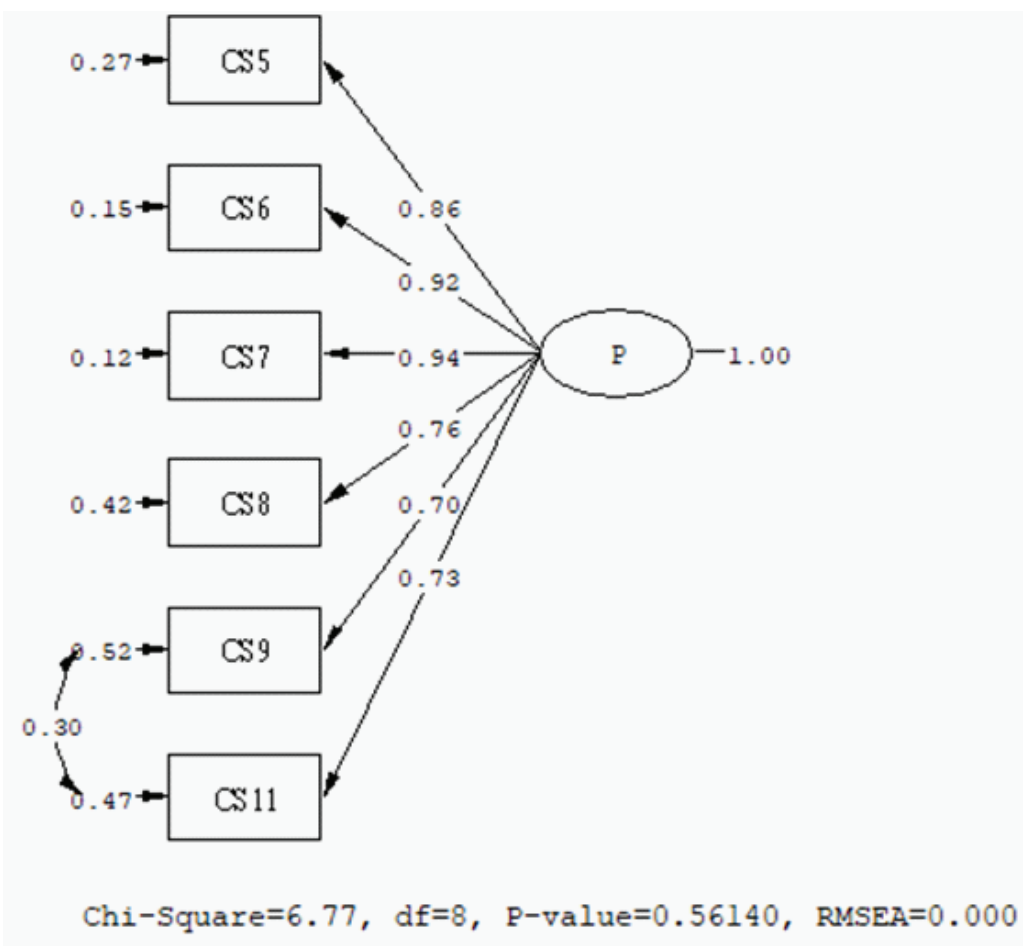


Appendix B6: Measurement model of entrepreneurial experience.

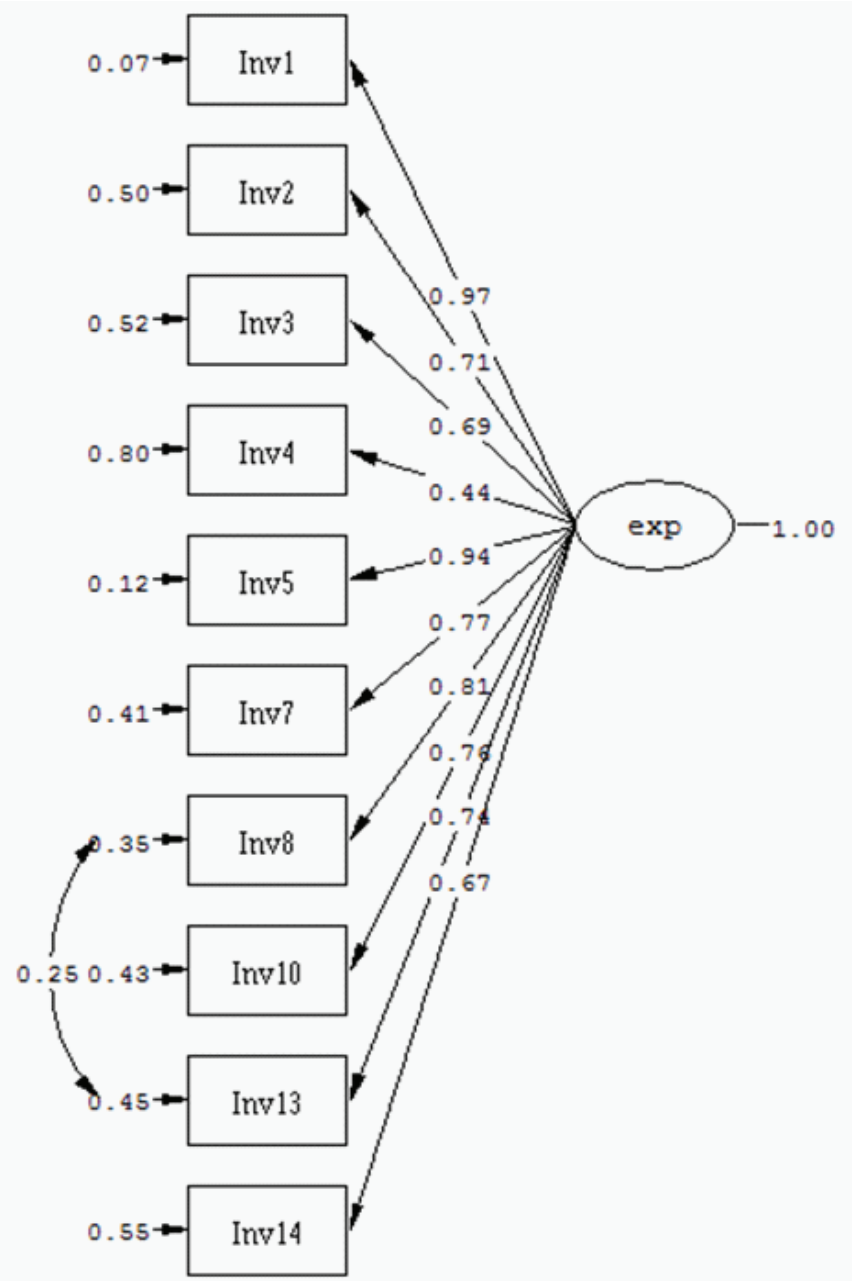

Chi-Square $=36.04, d f=34, P-$ value $=0.37308$, RMSEA $=0.038$ 